\title{
Literal, fictive and metaphorical motion sentences preserve the motion component of the verb: A TMS study
}

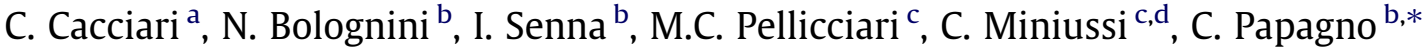 \\ a Department of Biomedical Sciences, University of Modena E Reggio-Emilia, Italy \\ ${ }^{\mathrm{b}}$ Department of Psychology, University of Milano-Bicocca, Italy \\ ${ }^{\text {c } C o g n i t i v e ~ N e u r o s c i e n c e ~ S e c t i o n, ~ I R C C S ~ S a n ~ G i o v a n n i ~ d i ~ D i o ~ F a t e b e n e f r a t e l l i, ~ B r e s c i a, ~ I t a l y ~}$ \\ ${ }^{\mathrm{d}}$ Department of Biomedical Sciences and Biotechnologies, National Institute of Neuroscience, University of Brescia, Italy
}

\section{A R T I C L E I N F O}

\section{Article history:}

Accepted 23 May 2011

\section{Keywords:}

TMS

Motor evoked potentials

Motion verb

Idiom

Metaphor

Fictive motion

\begin{abstract}
A B S T R A C T
We used Transcranial Magnetic Stimulation (TMS) to assess whether reading literal, non-literal (i.e., metaphorical, idiomatic) and fictive motion sentences modulates the activity of the motor system. Sentences were divided into three segments visually presented one at a time: the noun phrase, the verb and the final part of the sentence. Single pulse-TMS was delivered at the end of the sentence over the leg motor area in the left hemisphere and motor evoked potentials (MEPs) were recorded from the right gastrocnemius and tibialis anterior muscles. MEPs were larger when participants were presented with literal, fictive and metaphorical motion sentences than with idiomatic motion or mental sentences. These results suggest that the excitability of the motor system is modulated by the motor component of the verb, which is preserved in fictive and metaphorical motion sentences.
\end{abstract}

(c) 2011 Elsevier Inc. All rights reserved.

\section{Introduction}

Convergent evidence has lead to the claim that the organization of conceptual knowledge in semantic memory closely reflects the association with the dominant sensorimotor channels of experience for a given concept (Martin, 2007; Patterson, Nestor, \& Rogers, 2007). This claim is consistent with Embodied Cognition theories that ground cognition in bodily experience and mental simulation (Barsalou, 1999; Fischer \& Zwaan, 2008; Ghio \& Tettamanti, 2010; Glenberg et al., 2008). Behavioral, physiological and neuroimaging studies have demonstrated the involvement of the motor system in processing the action-related content of linguistic utterances (Pulvermüller \& Fadiga, 2010). For example, listening to body-part specific action sentences (e.g., I bite an apple, I grasp a knife, I kick a ball) activates a left fronto-parieto-temporal circuit with somatotopic organization in the premotor cortex (Tettamanti et al., 2005). However, such results have been challenged by other neuroimaging studies (Galati et al., 2008; Postle, McMahon, Ashton, Meredith, \& de Zubicaray, 2008). To reconcile these diverging results, Fernandino and Iacoboni (2010) proposed that the neuroanatomical variability between body-part specific activation foci reported in the literature may be explained assuming that the motor and premotor cortices contain multiple, functionally distinct,

* Corresponding author. Address: Dipartimento di Psicologia, Università di Milano-Bicocca, Piazza dell'Ateneo Nuovo 1-Edificio U6, 20126 Milano, Italy. Fax: +390264483706.

E-mail address: costanza.papagno@unimib.it (C. Papagno). representations of each body part forming a discontinuous topography with many overlapping maps. The exact location of the somatotopic foci for action-related language may reflect language-motor correspondences involving different topographic maps that vary according to the type of stimuli (e.g., single words vs. sentences), linguistic characteristics (e.g., transitive vs. intransitive verbs) and task.

Recent evidence has shown that the activation of dedicated action-selection neural mechanisms mediated by the left dorsal premotor cortex enhances the comprehension of action-related sentences in sport individuals (e.g., hockey players) whose motor skill repertoire reflects the very same actions described by the sentences (Beilock, Lyons, Mattarella-Micke, Nusbaum, \& Small, 2008). These results suggest that the comprehension of action-related language may not depend on the activation of the motor system but can be enhanced by it (Fischer \& Zwaan, 2008).

However, action-related verbs can be used in several ways. When someone says The road turns left, it is evident that she/he does not refer to a physical entity moving: this type of sentence conveys fictive motion (Talmy, 2000). An actual change of location is instead implied in literal sentences such as The man turns left. But there are further possibilities: for instance, the verb turn can be used metaphorically as in The lady turns her thought away from sorrow, or idiomatically as in I want to turn page (an Italian idiom roughly equivalent to the American idiom turn a new leaf). TMS and fMRI studies on the involvement of action-related brain systems in the comprehension of figurative language do not provide a consistent picture. In some TMS studies (e.g., Buccino et al., 
2005), action-related verbs elicited greater activation in the primary motor cortex depending on the effector implied in the action (foot-leg or hand), but abstract actions did not produce any significant activation. In other studies (e.g., Glenberg et al., 2008) no difference was found between concrete transfer verbs (e.g., to give cards to someone) and abstract transfer verbs (e.g., to delegate responsibilities to someone) (since both modulated motor evoked potentials amplitude when compared to nontransfer verbs). The picture emerging from fMRI studies using metaphorical and idiomatic sentences is rather complex as well (e.g., Aziz-Zadeh, Wilson, Rizzolatti, \& Iacoboni, 2006; Boulenger, Hauk, \& Pulvermüller, 2009; Chen, Widick, \& Chatterjee, 2008; Raposo, Moss, Stamatakis, \& Tyler, 2009; Tettamanti et al., 2005). In general, action-related sentences elicited activation in the premotor and motor cortex with a somatotopically-congruent distribution, while metaphorical and idiomatic sentences did not. Indeed, in Aziz-Zadeh et al.'s (2006) study, a clear congruence was found between effector-specific activations of visually presented actions and of actions conveyed by literal sentences, but no effect emerged for metaphorical ones. However, the constituents of these sentences, except the verb, referred to abstract concepts (e.g., grasping the idea, time is running) and this might have affected motor activation. In contrast, Boulenger et al. (2009) found activation for both idiomatic and literal sentences along the motor strip in the central and precentral cortex that somatotopically corresponded to the body part reference of the words. Yet, the activated cortical areas included those generally involved in idiom comprehension (Romero Lauro, Tettamanti, Cappa, \& Papagno, 2008; Zempleni, Haverkort, Renken, \& Stowe, 2007) casting doubts on the specific contribution of motor areas to these activations. Moreover, activation occurred at a late stage suggesting a possible intervention of additional factors such as individual comprehension strategies: participants might have tried to make sense of idiomatic meanings forming mental images. Several sources of evidence on languageimpaired and unimpaired participants suggest that whenever an image is selected to represent an idiomatic (or metaphorical) sentence, it corresponds to the literal (and not figurative) meaning of the string (Cacciari \& Glucksberg, 1995; Papagno \& Caporali, 2007). In Chen et al.'s study (2008) metaphorical motion produced greater activation in the left frontal inferior cortex and in the left lateral temporal lobe compared to literal motion. However, the contrast between sentences conveying literal motion and non-motion did not show significant activation. Wallentin et al. (2005) found activation in the left posterior middle temporal cortex (motionsensitive visual areas and not motor areas) for both fictive and non-fictive motion sentences suggesting that participants performed a mental scanning of the scenario conveyed by fictive motion sentences (Talmy, 2000). Saygin, McCullough, Alac, and Emmorey (2010) studied the behavior of motion-sensitive visual areas during audio-visual presentation of fictive motion sentences. Consistently with Wallentin et al.'s findings, Saygin et al. reported that fictive motion sentences activated motion-sensitive visual areas although to a lesser extent than literal motion sentences. Both studies provide evidence of an involvement of visual motion temporal cortex, but they did not show a specific recruitment of motor and premotor areas in fictive motion sentence comprehension.

To sum up, positive but also negative evidence exists on the involvement of motor regions in the comprehension of sentences that contain motion verbs without conveying any actual movement. This might be due, at least in part, to differences in the tasks (e.g., morphological tasks, semantic judgments, mental simulations of actions) and sometimes also to the experimental materials, especially when figurative sentences are included. For example, defining what an idiom is or the difference between an idiom and other types of figurative expression (e.g., metaphor, proverb, cliché, and collocation) might seem a useless task. However, there is an underestimation of the role played by the linguistic characteristics of the stimuli employed in experimental and clinical studies, and very often researchers mistake an idiom for a proverb or for a metaphor (for a discussion, see Cacciari \& Papagno, in press). In fact these expressions differ from a semantic and syntactic point of view and ignoring these differences may represent a serious confound in language research (see Papagno \& Caporali, 2007; Papagno, Tabossi, Colombo, \& Zampetti, 2004).

Therefore our aim was to clarify the role of motor area activation using in the same study motion verbs employed in literal and non-literal ways, potentially eliminating the methodological differences that might have contributed to the nonhomogenous results found in the literature. To this aim, motor evoked potentials (MEPs) were recorded from right inferior limb muscles (the motion verbs of this study were leg-based) and from the first dorsal interosseus (as control) while delivering single-pulse TMS on the left primary motor cortex. Variations of the motor cortex excitability indexed by MEPs should provide a measure of the involvement of the motor system. An increased cortical excitability induces an increase in MEP amplitude, whereas a decrease in cortical excitability produces a decrease in MEP amplitude (e.g. Rothwell, Day, Thompson, Dick, \& Marsden, 1987). Consistent evidence indicates a functional link between motor area and language. Indeed, processing sentences or verbs describing actions has been shown to involve, in addition to classic language areas, the motor and premotor cortex. Therefore, if a language task can modulate the excitability of the motor area, it should also modulate the size of MEP responses. In this respect, the MEP amplitude provides a measure of the involvement of the motor area in a given task (for a review, see Devlin \& Watkins, 2007).

In this study, motion verbs were used in four different ways that, in our hypothesis, can trigger different modulations of the activity of the motor system. In literal sentences, the motion verb conveyed an actual movement of an animate agent. Therefore we expected to find activation of the motor cortex, as in many previous studies. In metaphorical sentences (e.g., The girl follows her instinct in all cases), the motion verb does not take its default argument in the subject or object position. However, following a behavioral claim proposed by Torreano, Cacciari, and Glucksberg (2005), we hypothesized that the motion component of the verb is preserved not only in literal but also in metaphorical sentences: in both cases a motion is implied, but in the metaphorical sense the motion verb is used at a higher level of abstraction to refer to any instance of goal-driven conjoint motion. The third type of motion manipulated in this study was fictive motion: by definition, an inanimate subject (e.g., road, railway or path) is coupled with a motion verb to convey a non-concrete, static meaning. Fictive motion sentences convey a spatial relation between a path (or linear event) and a landmark (Matlock, 2004; Richardson \& Matlock, 2007; Saygin et al., 2010; Talmy, 2000; Wallentin et al., 2005). As Talmy (2000) claimed, fictive motion sentences maintain the spatial framework and landmarks of concrete motion sentences with the reader mentally scanning the described space. If so (see Wallenstin et al., and Saygin et al.'s results), fictive motion sentences might preserve many of the characteristics that are typical of sentences conveying concrete spatial changes. Consequently, fictive motion sentences should elicit activation of the motor system and not only of motion-sensitive visual areas. In contrast, and differently from literal, metaphorical and fictive motion sentences, the motion component of the verb might be vanished in idiomatic sentences since the relationship between the idiom constituent words and the idiomatic meaning generally is arbitrary and learned. The semantic structure of an idiom is typically formed by a concrete (literal) action that conveys a mental state that has nothing to do with a change of location (as for instance in the Ital- 
ian idiom to run a risk). Therefore, we did not expect to find motor cortex activation for idiomatic motion verbs.

Our prediction of motor system activation in literal, metaphorical and fictive motion sentences is compatible with the claim that sentences are understood by creating a mental simulation of the described action (Glenberg \& Robertson, 1999). If we posit that this mental simulation occurs also when an abstract sense of change of location is conveyed, we can predict motor activation for literal as well as for metaphorical and fictive motion sentences, but not for idiomatic ones.

\section{Methods}

\subsection{Participants}

Nine healthy participants (mean age 27 years, range 24-34; mean education $17 \pm 1$ years) were enrolled in the experiment. One subject was excluded from the analysis since her MEPs' area was 2.5 SDs above the mean for each condition. We chose to test only female subjects to control for possible influence of hormonal status on cortical excitability (Smith et al., 1999; see below for further details).

Participants were native Italian graduate students. None of them reported neurological, psychiatric or other relevant medical problems, or any contraindication to TMS (Rossi, Hallett, Rossini, Pascual-Leone, \& Safety of TMS Consensus Group, 2009). All participants had normal or corrected to normal visual acuity, and were right-handed, as assessed by the Handedness Inventory Test (Briggs \& Nebes, 1975). The mean score was $85.9 \%$. We also tested the right-leg dominance of the participants involved in the main Experiment using the revised Lateral Preference Inventory (Coren, 1993) where their mean score was $83.1 \%$. Participants gave informed consent. The experimental protocol was approved by the local Ethical Committee and was carried out in accordance with the Declaration of Helsinki.

\subsection{Materials}

We selected 27 familiar Italian verbs expressing a movement that involved the legs (e.g., run). For each motion verb we created four types of sentence: (1) Literal sentences (e.g., The man runs in the beautiful country); (2) Metaphorical sentences (e.g., The woman runs with her fantasy often); (3) Idiomatic sentences (e.g., Between the neighbors runs bad blood); (4) Fictive motion sentences (e.g., The road runs along the impetuous river). The four sentences created for each verb had the same verbal tense. Twenty-seven sentences of similar length and syntactic structure containing a mental verb were created as control sentences (e.g., Cristina considers the idea very interesting). The subject of the experimental sentences was always animate, except in the case of fictive motion sentences and in three metaphorical sentences.

The psycholinguistic characteristics of the stimuli that are known to affect comprehension latencies were controlled as follows: a written booklet containing the 108 sentences was presented to 20 participants (different from those involved in the TMS experiments) who were asked to assign a concreteness rating to the sentential meaning (from $0 \%$ : no concrete action at all, to $100 \%$ : totally concrete action). The mean concreteness percentages are reported in Table 1. Basically, literal sentences were judged as conveying a concrete action and much less so (or barely) all the other types of sentence. The Age of Acquisition and the written frequency (COLFIS; Bertinetto et al., 2005) of each mental verb were matched to those of the paired motion verb. The written frequencies of the sentential subjects and content words of the third segments were balanced (see Table 1). A different group of twenty participants was asked to rate on a 7-point scale the comprehensibility of the sentences (from 1: not at all comprehensible, to 7: fully comprehensible). The mean comprehensibility values are reported in Table 1 and they show that all sentences were highly comprehensible (range 5.8-6.8 on a 7-point scale). The mean number of words of the five sentence types was balanced.

In sum, the sentences were balanced for length and constituent words frequency and had comparably high comprehensibility scores.

For the 27 idioms, we controlled how much the idiom meaning was known (idiom familiarity), and how much the meaning of the words composing each idiom string contributed to the figurative meaning (semantic transparency) (see Table 1). We asked 21 additional participants to rate each idiom on two rating scales (from 1: unfamiliar idiom/individual words do not contribute at all, to 7: totally familiar idiom/individual words contribute very much). The idioms were familiar (mean familiarity: 4.9, SD 0.34) but differed in the extent to which they were judged as semantically transparent (range 2.1-6.8), as it is often the case with this metalinguistic judgment. The Italian stimuli, with English translations, are reported in Table 2 .

\subsection{TMS procedure and data acquisition}

The left motor area was stimulated by means of single-pulse TMS, contralaterally to the recorded muscles. Magnetic stimuli were delivered through a double cone coil (external wing diameter $110 \mathrm{~mm}$ ) placed with the handle oriented in the perpendicular direction with respect to the scalp over the left motor cortex (M1) and connected to a Magstim SuperRapid magnetic stimulator (Magstim Company, Whitland, UK).

Motor evoked potentials (MEPs) were recorded on the right side from gastrocnemius (GCM), and tibialis anterior (TA). We chose the inferior limb since the effectors involved in all sentences mainly included leg muscles. Additionally, we recorded MEPs from the first dorsal interosseous (FDI) muscle. Pairs of $\mathrm{Ag} / \mathrm{AgCl}$-coated surface recording electrodes were placed over each single muscle with a reference-electrode at a $2 \mathrm{~cm}$-distance. The optimal site of stimulation for eliciting MEPs in the right GCM and TA, the common motor hotspot, was chosen by positioning the coil approximately over the central sulcus and moving it onto the scalp in $1 \mathrm{~cm}$ steps over the left M1 cortex. The motor hotspot was assessed at a moderately suprathreshold stimulation intensity and marked directly on the scalp with a soft-tip pen. On this site, the individual resting motor threshold (RMT) was determined as the stimulator intensity necessary to produce a response of amplitude of at least $50 \mu \mathrm{V}$, in the relaxed GCM and TA in at least five out of 10 consecutive stimulations with a resolution of $1 \%$ of the maximal stimulator output (Rossini et al., 1994). Once the optimal scalp site was found, the coil was maintained in position using a mechanical coil holder. The mean motor threshold was $51 \pm 6 \%$ of the maximum stimulator output. The stimulation intensity during the experiment was set at $120 \%$ of participant's RMT. Complete muscle relaxation was monitored throughout the experimental session. Participants tolerated TMS stimuli well and no adverse effects were reported.

Attention was paid to potential confounding variables like the menstrual cycle phase, circadian effects, sportive activity and participants' height. In particular, the experimental session was carried out during the early follicular phase of participants' menstrual cycle, between the 4th and 10th day from the start of the cycle (Smith et al., 1999), and at the same time period of the day (i.e., 10-12 a.m.) (Sale, Ridding, \& Nordstrom, 2007). All participants reported a low sportive activity at a self-report questionnaire. Their height did not significantly differ (mean $164 \pm 4 \mathrm{~cm}$ ). During the experimental session, participants were seated in a comfortable chair in front of a computer screen at a distance of 
Table 1

Mean concreteness, written frequency, comprehensibility, and semantic transparency of the stimuli used in the experiment.

\begin{tabular}{|c|c|c|c|c|c|c|c|c|c|c|}
\hline \multirow{2}{*}{$\begin{array}{l}\text { Type of sentence } \\
\text { Type of sentence subject }\end{array}$} & \multicolumn{2}{|l|}{ Literal } & \multicolumn{2}{|l|}{ Metaphorical } & \multicolumn{2}{|l|}{ Fictive } & \multicolumn{2}{|l|}{ Idiomatic } & \multicolumn{2}{|l|}{ Mental } \\
\hline & $\begin{array}{l}\text { Proper name } \\
15\end{array}$ & $\begin{array}{l}\text { NP } \\
12\end{array}$ & $\begin{array}{l}\text { Proper name } \\
11\end{array}$ & $\begin{array}{l}\mathrm{NP} \\
16\end{array}$ & $\begin{array}{l}\text { Proper } \\
\text { name } 0\end{array}$ & $\begin{array}{l}\text { NP } \\
27\end{array}$ & $\begin{array}{l}\text { Proper } \\
\text { name } 7\end{array}$ & $\begin{array}{l}\text { NP } \\
20\end{array}$ & $\begin{array}{l}\text { Proper name } \\
20\end{array}$ & $\begin{array}{l}\text { NP } \\
7\end{array}$ \\
\hline Written frequency of the sentence subject & \multirow{2}{*}{\multicolumn{2}{|c|}{$\begin{array}{l}280.01(177) \\
236.7(389)\end{array}$}} & \multirow{2}{*}{\multicolumn{2}{|c|}{$262(175)$}} & \multirow{2}{*}{\multicolumn{2}{|c|}{$308(240)$}} & \multirow{2}{*}{\multicolumn{2}{|c|}{$\begin{array}{l}325(255) \\
211.7(354)\end{array}$}} & \multirow{2}{*}{\multicolumn{2}{|c|}{$270(184)$}} \\
\hline Written frequency of the verbs & & & & & & & & & & \\
\hline $\begin{array}{l}\text { Written frequency of the open class words in the } \\
\text { third segment }\end{array}$ & \multicolumn{2}{|l|}{-} & \multicolumn{2}{|l|}{$534.77(648)$} & \multicolumn{2}{|l|}{$515.18(627)$} & \multicolumn{2}{|l|}{$519.74(534)$} & \multicolumn{2}{|l|}{652.59 (549) } \\
\hline Number of words of the sentence & \multicolumn{2}{|l|}{$6.7(0.9)$} & \multicolumn{2}{|l|}{$6.4(0.8)$} & \multicolumn{2}{|l|}{$6.9(0.6)$} & \multicolumn{2}{|l|}{$6.8(1.0)$} & \multicolumn{2}{|l|}{$6.4(0.5)$} \\
\hline Sentence concreteness & \multicolumn{2}{|l|}{$96.7 \%(4.0)$} & \multicolumn{2}{|l|}{$3.1 \%(5.8)$} & \multicolumn{2}{|l|}{$25.4 \%(17.2)$} & \multicolumn{2}{|l|}{$6.4 \%(9.9)$} & \multicolumn{2}{|l|}{-} \\
\hline Sentence comprehensibility & \multicolumn{2}{|l|}{6.8 (SD 0.5) } & \multicolumn{2}{|l|}{$5.8($ SD 1.3$)$} & \multicolumn{2}{|l|}{$6.13(\mathrm{SD} 1.1)$} & \multicolumn{2}{|l|}{$6.3(\mathrm{SD} 1.1)$} & \multicolumn{2}{|l|}{$5.9(\mathrm{SD} 1.2)$} \\
\hline Idioms semantic transparency & \multicolumn{2}{|l|}{-} & & & & & \multicolumn{2}{|l|}{$4.4(1.2)$} & \multicolumn{2}{|l|}{-} \\
\hline Idioms familiarity & \multicolumn{2}{|l|}{-} & & & & & \multicolumn{2}{|l|}{$4.9(0.34)$} & \multicolumn{2}{|l|}{-} \\
\hline
\end{tabular}

Psycholinguistic characteristics of the experimental materials.

$80 \mathrm{~cm}$ with their legs in a relaxed position. The room was a soundproof Faraday-cage, dimly illuminated.

After establishing the stimulation threshold, a training session of five trials was run. In these sessions the stimuli were different from those included in the experimental set. During the training session, the TMS coil was placed over the motor cortex and a single TMS pulse was delivered at the same intensity and timing as in the subsequent experimental trials to accustom the participant to the scalp sensation and noise produced by the stimulator during task execution. The training session was immediately followed by the experimental session. The experimental session consisted of 135 (27 literal, 27 fictive, 27 metaphorical, 27 idiomatic and 27 mental) sentences randomly intermixed. Each sentence was divided into three segments that were presented one at a time: the noun phrase (that contained an animate subject, e.g., Cristina, The girl, except for fictive sentences), the verb (a motion or a mental verb, e.g., runs, thinks) and the remaining part of the sentence. Since the first two segments only contained the noun phrase and the verb, participants could assign a literal or non-literal interpretation to the sentential meaning only after reading the third segment, with the exception of the sentences with an inanimate subject.

Each sentential segment was presented using a black 16-point Courier New font on a white background of a 19-in. LCD monitor and controlled by the E-prime software (version 1.2, Psychological Tools, Inc) that was used also for TMS triggering. The three segments of each sentence were projected, one at a time, in the left, center and right part of the screen, respectively. Participants were instructed to read for comprehension. To control that this was the case, the participants were advised that at the end of the experiment they would have to perform a recognition test on the sentences presented in the experiment, after a short rest of about 5 min. Participants were presented with twenty sentences, 10 of which were part of the experiment (two for each sentence type) and 10 new sentences, similar in length and syntactic structure to the experimental ones. The threshold for including a participant in the analyses was $70 \%$ of correct recognition. No subject had to be excluded.

The duration of the presentation time of each segment was chosen based on a pilot test performed without TMS. This pilot test was run on 14 participants ( 9 females; mean age $23 \pm 1$ years; mean education $13 \pm 1$ years); none of them took part in the TMS experiment. They were presented with a sentence segment at a time and were asked to press a keyboard button as soon as they finished reading it. The sentences were randomly presented. A recognition test was included at the end also in this pilot test: 10 sentences belonging to the experimental materials and 10 new sentences with similar characteristics were presented to participants, who were asked to indicate which had been shown in the experiment. The mean reading times were $605 \mathrm{~ms}$ (SD $140 \mathrm{~ms}$ ) for the first segment, $647 \mathrm{~ms}$ (SD $234 \mathrm{~ms}$ ) for the second segment and $1184 \mathrm{~ms}$ (SD $457 \mathrm{~ms}$ ) for the last segment and they reflected the time necessary for reading for comprehension the three segments. Therefore these reading times were used to establish the presentation time for each segment: the first two segments were presented and remained on the screen for $600 \mathrm{~ms}$ each, while the third was presented for $1100 \mathrm{~ms}$ in both experiments.

A total of 140 pulses were delivered for each participant. Between two consecutive sentences there was an interval varying from a minimum of $2500 \mathrm{~ms}$ to a maximum of $5000 \mathrm{~ms}$.

A single-pulse TMS was given in coincidence with the end of the sentence (i.e., $2300 \mathrm{~ms}$ from onset of the sentence). This TMS pulse latency was chosen to allow full processing of the sentences. The experimental session lasted about $10 \mathrm{~min}$.

\subsection{Data and statistical analysis}

The TMS-induced MEPs recorded during the experimental task were filtered (bandpass $.015-1000 \mathrm{~Hz}$ ), digitized (sampling rate $5 \mathrm{kHz}$ using a 16 bit A/D-converter) and stored on a computer for off-line analysis (BrainAmp DC/MRplus, Brain Products GmbH, Munich, Germany). The skin-electrode impedance was kept below $5 \mathrm{k} \Omega$. The epoching of the MEPs was performed offline. All the data collected were epoched between -20 and +120 ms relative to the TMS stimulation and were referenced to the $20 \mathrm{~ms}$ pre-stimulus baseline. Epochs contaminated with voluntary electromyogram activity (19.7\%) were discarded from further analysis.

We measured the area underlying MEPs ( $\mu \mathrm{V}$ ms) of TA and GCM for each trial in each condition. This choice was due to the fact that TA and GCM responses were polyphasic. The average area values were submitted to a repeated measures analysis of variance (ANOVA). In the case of MEPs recorded from the TA and GCM the ANOVA model included two within-subject factors: Muscle (two levels: TA and GCM) and Sentence type (five levels: literal, fictive, metaphorical, idiomatic and control mental). In five out of nine subjects, TMS also induced MEPs from the right FDI. Also these data were analyzed using a repeated measure ANOVA with Sentence type as within subject factor. The significance level was always set at .05. Post-hoc comparisons were carried out using Newmann-Keuls tests. Before running the analyses, the sphericity requirements for the repeated measures ANOVA were assessed by using the Mauchly's test for each data set (i.e., leg and hand data). Where the assumptions were not met, the Greenhouse-Geisser correction was used.

\section{Results}

The ANOVA carried out on MEPs recorded from the leg muscles showed that motion sentences selectively modulated MEPs in both the TA and the GCM. Indeed, the significant main effect of Sentence 
Table 2

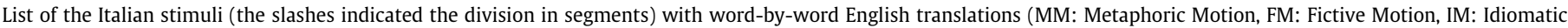
Motion, LM: Literal motion, C: Control mental sentences).

\begin{tabular}{|c|c|c|}
\hline Sentence & Type & English translation \\
\hline La fatica/viene/in punta di piedi sempre & MM & Tiredness/comes/on the tip of the toes always \\
\hline La vecchiaia/avanza/lentamente per lui & MM & Old age/moves forward/slowly for him \\
\hline La vincita/giunge/in modo inaspettato & MM & The winning/arrives/in an unexpected way \\
\hline Daniele/fugge/dalle responsabilità spesso & MM & Daniel/flees/from responsibilities often \\
\hline Fabio/entra/nei suoi pensieri quotidiani & MM & Fabio/goes/in his daily thoughts \\
\hline Giorgio/passa/attraverso dispiaceri purtroppo & MM & George/passes/through sorrows unfortunately \\
\hline Grazia/getta/via la vita disperata & MM & Grace/throws/away her life desperately \\
\hline Il ballerino/sale/nelle graduatorie finali & MM & The dancer/gets up/in the final ranking \\
\hline Il monaco/cammina/verso la fede sempre & MM & The monk/walks/towards the faith \\
\hline Il ragazzo/si allontana/dagli affetti familiari & MM & The boy/goes away/from family love \\
\hline Il signore/si tuffa/nel lavoro di ufficio & MM & The man/dives/in the office work \\
\hline La ragazza/scende/nei particolari troppo & MM & The girl/goes down/in the detail too much \\
\hline La ragazza/segue/il suo istinto sempre & MM & The girl/follows/her instinct always \\
\hline La signora/corre/con la fantasia spesso & MM & The woman/runs/with her fantasy often \\
\hline La signora/esce/dai pensieri del marito & MM & The woman/goes out/of her husband's thoughts \\
\hline La signora/volta/la mente alle difficoltà & MM & The woman/turns/the mind to difficulties \\
\hline Lo studente/salta/da un libro all'altro & MM & The student/jumps/from one book to the other \\
\hline Luciano/attraversa/molte difficoltà con coraggio & MM & Luciano/crosses/several difficulties with bravery \\
\hline L'uomo/raggiunge/l'obiettivo prefissato & MM & The man/gets/to the given objective \\
\hline Maria/si perde/nei pensieri sul futuro & MM & Mary/looses herself/in thoughts about the future \\
\hline Marina/si avvicina/alla verità inaspettatamente & MM & Marina/approaches/to the truth unexpectedly \\
\hline Marta/percorre/la strada del declino purtroppo & MM & Marta/walks/over the decay road regrettably \\
\hline Martino/si arrampica/con le parole spesso & MM & Martino/climbs/with the words often \\
\hline Mauro/va incontro/alla disperazione più nera & MM & Mauro/goes towards/the blackest desperation \\
\hline Monica/si butta/via senza ritegno & MM & Monica/throws herself/away without restraint \\
\hline Roberto/arriva/alla conclusione giusta & MM & Robert/arrives/to the right conclusion \\
\hline Sara/si muove/fra mille difficoltà ormai & MM & Sara/moves herself/among thousands of difficulties by then \\
\hline La strada/fugge/tra i campi coltivati & FM & The road/flees/among the tilled fields \\
\hline Il lavoro/avanza/a fatica in ufficio & FM & The job/advances/with effort in the office \\
\hline Il pilone/si tuffa/nel mare profondo & FM & The pylon/dives/in the deep sea \\
\hline La strada/viene/dritta in paese & FM & The road/comes/straight in the village \\
\hline Il sentiero/attraversa/la valle fiorita & FM & The path/crosses/the valley in blossom \\
\hline La pista/giunge/ai piedi della valle & FM & The trail/arrives/to the bottom of the valley \\
\hline La strada/cammina/parallela al fiume & FM & The road/walks/parallel to the river \\
\hline Il viottolo/si arrampica/sulla collina irta & FM & The track/climbs/over the rocky hill \\
\hline La curva/si getta/a sinistra improvvisamente & FM & The bend/throws/left suddenly \\
\hline La strada/corre/lungo il fiume impetuoso & FM & The road/runs/along the wild river \\
\hline La ferrovia/segue/il corso del fiume & FM & The railway/follows/the course of the river \\
\hline Il sentiero/si perde/fra i cespugli folti & FM & The path/looses itself/among the thick bushes \\
\hline La strada/passa/vicino al lago alpino & FM & The road/passes/near to the alpine lake \\
\hline La pista/esce/dal confine italiano & FM & The trail/goes out/from the Italian boundary \\
\hline La strada/sale/fino al paese ripida & FM & The road/goes up/until the village steeply \\
\hline La strada/si muove/lungo il fiume arido & FM & The road/moves/along the dry river \\
\hline La recinzione/va/oltre il confine straniero & FM & The fence/goes/beyond the foreign border \\
\hline La strada/arriva/nel centro di Napoli & FM & The road/arrives/in the center of Naples \\
\hline Il burrone/si avvicina/alla via pericolosamente & FM & The ravine/approaches/the road dangerously \\
\hline La strada/volta/a sinistra bruscamente & FM & The road/turns/left sharply \\
\hline La vetta/si allontana/per il bravo scalatore & FM & The top/goes away/for the good climber \\
\hline La pista/scende/dalle montagne innevate & FM & The trail/descends/from the snowy mountain \\
\hline La ferrovia/salta/quel paese isolato & FM & The railway/jumps/that isolated village \\
\hline Il viottolo/entra/in paese dalla collina & FM & The path/goes in/the village from the hill \\
\hline La ferrovia/raggiunge/la cima della montagna & FM & The railway/reaches/the top of the mountain \\
\hline L'autostrada/percorre/il paese da tempo & FM & The highway/goes through/the country since then \\
\hline Il ponte/si butta/dentro l'orrido profondo & FM & The bridge/jumps into/the deep gorge \\
\hline Il lavoro/giunge/in porto fra difficoltà & $\mathrm{IM}$ & The job/arrives/in harbor among troubles (finishes) \\
\hline Il progetto/va/a monte purtroppo & IM & The project/goes/to the mountain unfortunately (fails) \\
\hline L'azienda/passa/di mano purtroppo & IM & The factory/passes by/from hand unfortunately (changes ownership) \\
\hline Fra i vicini/corre/cattivo sangue ormai & IM & Between the neighbors/runs/bad blood now (awful relationships) \\
\hline Alice/salta/di palo in frasca sempre & IM & Alice/jumps/from pole to branch always (from one thing to another) \\
\hline Cristiano/si avvicina/alla soluzione del problema & IM & Cristiano/approaches/the solution to the problem \\
\hline Diego/cammina/sul filo del rasoio spesso & IM & Diego/walks/on the edge of the razor often \\
\hline Enzo/entra/in ballo come candidato imbattibile & IM & Enzo/enters/in the ball as undefeatable candidate (into the competition) \\
\hline Giuseppe/segue/le orme del padre ormai & IM & Giuseppe/follows/the footprints of the father by then (is inspired by) \\
\hline Il diplomatico/si muove/coi piedi di piombo & IM & The diplomat/moves/with feet of lead (is very careful) \\
\hline Il dirigente/sale/in cattedra spesso & IM & The manager/goes up/to the desk often (lays down the law) \\
\hline Il missionario/percorre/una strada difficile & IM & The missionary/goes through/a difficult road (meets several troubles) \\
\hline Il politico/esce/di scena velocemente & IM & The politicians/goes out/from scene rapidly (leaves) \\
\hline Il ragazzo/fugge/dalle cattive compagnie spesso & IM & The boy/escapes/from bad companies often (leaves dangerous friends) \\
\hline La ragazza/si allontana/dalla mente del fidanzato & IM & The girl/goes away/from the mind of her boyfriend (leaves) \\
\hline La spia/getta/la maschera alla fine & IM & The spy/throws/the mask at the end (is discovered) \\
\hline L'ambizioso/avanza/a capo chino spesso & IM & The ambitious/advances/with low head often (is tenacious) \\
\hline L'avvocato/si tuffa/nella mischia con piacere & IM & The lawyer/dives/into the crowd with pleasure (fights) \\
\hline Lo studente/raggiunge/un traguardo inaspettato & IM & The student/reaches/an unexpected finishing line \\
\hline
\end{tabular}


Table 2 (continued)

\begin{tabular}{|c|c|c|}
\hline Sentence & Type & English translation \\
\hline Lo studente/si perde/in un bicchiere d'acqua spesso & IM & The student/gets lost/in a glass of water often \\
\hline L'uomo/volta/le spalle alla moglie nuovamente & IM & The man/turns/his shoulders to the wife again (leaves) \\
\hline Mario/scende/dal pero nel dibattito & IM & Mario/goes down/from the pear tree in the discussion (becomes suddenly aware of something) \\
\hline Paola/attraversa/un brutto quarto d'ora & IM & Paola/crosses/a bad quarter of hour (is in troubles) \\
\hline Paolo/arriva/al capolinea ormai & IM & Paolo/arrives/at the terminus by then (has finished) \\
\hline Rita/si arrampica/sugli specchi spesso & IM & Rita/climbs herself/on the mirrors often (has serious difficulties) \\
\hline Stefania/si butta/a capofitto nell'impresa & IM & Stefania/throws herself/head first into the business \\
\hline Stefano/viene/alle mani coi compagni & IM & Stefano/comes/to hands with his friends (fights) \\
\hline Carla/corre/a casa con la spesa & LM & Carla/runs/home with the errands \\
\hline La ragazza/attraversa/la strada trafficata & LM & The girl/crosses/the street full of traffic \\
\hline Il poliziotto/segue/il ladro per la strada & LM & The policemen/follows/the thief in the street \\
\hline Roberto/arriva/all'incontro in orario & LM & Roberto/arrives/to the meeting in time \\
\hline Rosa/scende/in fretta dal treno & LM & Rosa/goes down/rapidly from the train \\
\hline Il bambino/fugge/dalla stanza in lacrime & LM & The child/escapes/from the room in tears \\
\hline Giulio/si allontana/da casa spesso ormai & LM & Giulio/goes away/from home often now \\
\hline Anna/raggiunge/il vicino supermercato & LM & Anna/reaches/the close supermarket \\
\hline Un turista/si perde/in molte città giapponesi & LM & A tourist/gets lost/in many japanese towns \\
\hline Aldo/va/a casa in bicicletta & LM & Aldo/goes/home with the bike \\
\hline La signora/viene/poco in città ormai & LM & The lady/comes/a few times in town \\
\hline Domenico/sale/lentamente in autobus & LM & Domenico/goes up/slowly in the bus \\
\hline Il gatto/passa/sul muretto assolato spesso & LM & The cat/crosses/the sunny wall often \\
\hline Filippo/cammina/sulla spiaggia deserta & LM & Filippo/walks/on the desert beach \\
\hline Claudia/salta/la corda in cortile & LM & Claudia/jumps/the rope in the garden \\
\hline Elisabetta/volta/il vassoio d'argento antico & LM & Elisabetta/turns/the old ancient tray \\
\hline Il bambino/si muove/nella culla molto spesso & LM & The baby/moves//in the cradle very often \\
\hline L'alpinista/si arrampica/sulla parete & LM & The alpinist/climbs up/on the wall \\
\hline Guido/esce/dalla grande aula magna & LM & Guido/goes out/from the big main room \\
\hline La bambina/entra/in classe molto felice & LM & The girl/goes in/the room very happy \\
\hline Il soldato/avanza/nella città occupata & LM & The soldier/advances/in the occupied city \\
\hline La guida/percorre/un lungo sentiero difficile & LM & The guide/goes through/a long difficult path \\
\hline Caterina/si butta/in acqua con eleganza & LM & Caterina/jumps/in the water elegantly \\
\hline Lucia/si tuffa/nell'acqua della gelida piscina & LM & Lucia/dives/in the water of the icy pool \\
\hline Mara/getta/via la sigaretta consumata & LM & Mara/throws/the consumed cigarette \\
\hline Angela/si avvicina/alla sua macchina lentamente & LM & Angela/approaches/her car slowly \\
\hline Il postino/giunge/in orario ogni giorno & LM & The postman/arrives/in time every day \\
\hline Antonia/si illude/sull'amore del marito & $\mathrm{C}$ & Antonia/deceives herself/on her husband's love \\
\hline Carlo/crede/in Babbo Natale davvero & $\mathrm{C}$ & Carlo/believes/in Babbo Natale indeed \\
\hline Corrado/avverte/il freddo ormai pungente & $\mathrm{C}$ & Corrado/notices/the deep cold now \\
\hline Cristina/ritiene/l'idea molto interessante & $\mathrm{C}$ & Cristina/conceives/the idea very interesting \\
\hline Fabrizio/progetta/le ferie con ansia & $\mathrm{C}$ & Fabrizio/plans/vacations anxiously \\
\hline Francesca/medita/sul quadro a lungo & $\mathrm{C}$ & Francesca/meditates/on the picture for a long time \\
\hline Francesco/spera/in una promozione futura & $\mathrm{C}$ & Francesco/hopes/for a future promotion \\
\hline Franco/sente/un dolore improvviso nel fianco & $\mathrm{C}$ & Franco/feels/a sudden pain in his hip \\
\hline Giulia/pretende/rispetto dal figlio adolescente & $\mathrm{C}$ & Giulia/wants/respect from her adolescent son \\
\hline Il bambino/vuole/un giocattolo nuovo spesso & $\mathrm{C}$ & The child/wants/a new toy often \\
\hline Il padrone/garantisce/un aumento di stipendio & $\mathrm{C}$ & The employer/grants/a salary increase \\
\hline Il professore/concede/qualche minuto in più & $\mathrm{C}$ & The professor/leaves/some more minutes \\
\hline La nonna/sta/molto tempo al mare & $\mathrm{C}$ & The grandmother/spends/a lot of time at the seaside \\
\hline La ragazza/conosce/la risposta dell'esame & $\mathrm{C}$ & The girl/knows/the answer at the exam \\
\hline Laura/sogna/la nuova casa estiva & $\mathrm{C}$ & Laura/dreams/her new vacation house \\
\hline L'operaio/attende/la pensione statale & $\mathrm{C}$ & The worker/waits for/the state pension \\
\hline Luca/ottiene/un voto alto all'esame & $\mathrm{C}$ & Luca/gets/a high grade at the exam \\
\hline L'uomo/critica/la soluzione del problema & $\mathrm{C}$ & The man/questions/the solution to the problem \\
\hline Mario/pensa/alla torta di cioccolata & $\mathrm{C}$ & Mario/thinks/about the chocolate cake \\
\hline Martino/teme/le conseguenze negative del lavoro & $\mathrm{C}$ & Martino/is worried/about the negative consequences of the job \\
\hline Matteo/desidera/la macchina da corsa & $\mathrm{C}$ & Matteo/wishes/the speedy car \\
\hline Michele/si convince/della nuova teoria ormai & $\mathrm{C}$ & Michele/is convinced/of the new theory now \\
\hline Riccardo/capisce/la soluzione del quiz & $\mathrm{C}$ & Riccardo/understands/the solution to the quiz \\
\hline Sandra/sospetta/il tradimento del fidanzato & $\mathrm{C}$ & Sandra/suspects/the betrayal of the fiancé \\
\hline Serena/propone/una cura per la malattia & $\mathrm{C}$ & Serena/proposes/a treatment for the illness \\
\hline Silvia/accetta/l'incarico con piacere & $\mathrm{C}$ & Silvia/accepts/the job with pleasure \\
\hline Valeria/ascolta/la lezione con interesse & $\mathrm{C}$ & Valeria/listens to/the lesson with interest \\
\hline
\end{tabular}

type $\left[F(4,28)=9.02, p<0.0001 p \eta^{2}=0.57\right]$ showed that, regardless of the muscle, MEPs for literal motion sentences $(1.13 \mu \mathrm{V} * \mathrm{~ms})$ were significantly higher than MEPs for mental sentences $(0.96 \mu \mathrm{V} * \mathrm{~ms}, \quad p<0.001)$ and for idiomatic motion sentences $(1.01 \mu \mathrm{V} * \mathrm{~ms}, p<0.01)$, while they did not differ from MEPs for metaphorical $(1.1 \mu \mathrm{V} * \mathrm{~ms}, p=0.2)$ and fictive motion sentences $(1.12 \mu \mathrm{V} * \mathrm{~ms} p=0.6)$. Moreover, MEPs recorded for mental sentences significantly differed from those recorded for literal motion sentences $(p<0.001)$, metaphorical motion sentences $(p<0.01)$ and fictive motion sentences ( $p<0.01)$, but not for idiomatic motion sentences ( $p=0.2$ ) (see Fig. 1 ).

The main effect of muscle was also significant $\left(F_{1,7}=18.73\right.$, $p<0.01, p \eta^{2}=0.73$ ), showing that MEPs recorded from the TA were higher than those recorded from the GCM. The interaction Muscle $\times$ Sentence did not reach significance $[F(4,28)=2.55$, $p=0.14, p \eta^{2}=0.27$ ).

Finally, reliable MEPs from the FDI muscle were elicited only in 5 out of 8 subjects. Therefore, the analysis was performed on a 

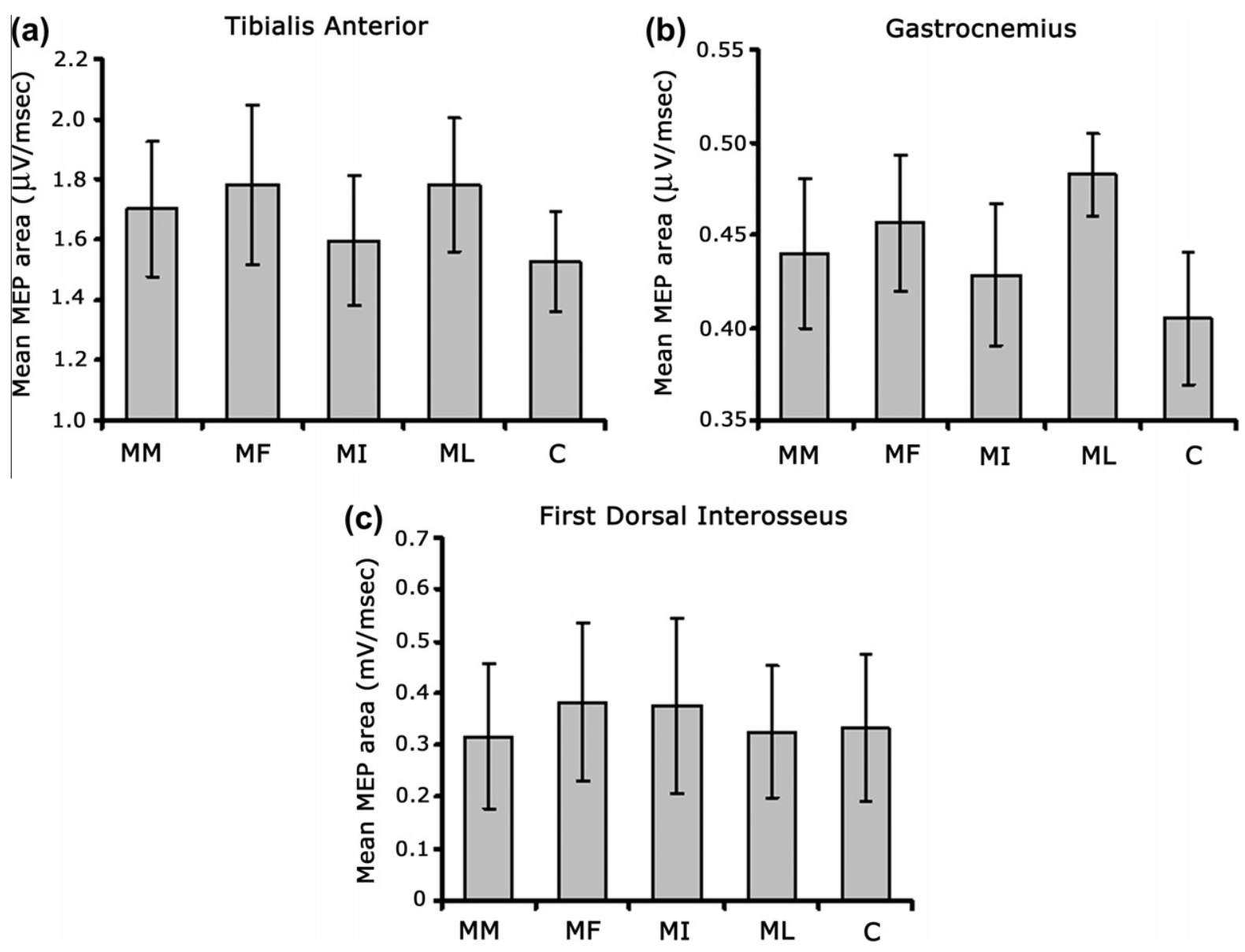

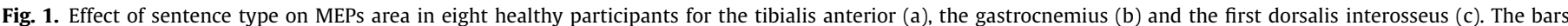

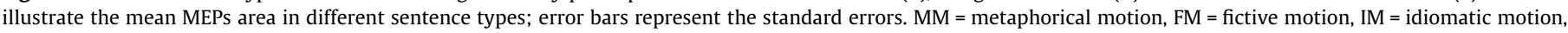
$\mathrm{LM}=$ literal motion, $\mathrm{C}=$ control $/$ mental verb.

limited number of participants. The ANOVA on MEPs recorded from the FDI did not show any significant main effect of Sentence type $[F(4,16)=1.62, p=0.3]$ showing that the effect of motion verbs was specific for leg muscles [metaphorical motion = $0.32 \mu \mathrm{Vms} \quad(\mathrm{SE}=0.14)$, fictive motion $=0.38 \mu \mathrm{Vms} \quad(\mathrm{SE}=0.15)$, idiomatic motion $=0.38 \mu \mathrm{V} \mathrm{ms} \quad(\mathrm{SE}=0.16)$, literal motion $=$ $0.33 \mu \mathrm{V}$ ms $\quad(\mathrm{SE}=0.13)$, mental sentence-control $=0.33 \mu \mathrm{V} \mathrm{ms}$ $(\mathrm{SE}=0.14)]$.

\section{General discussion}

The aim of this study was to determine the impact of literal and non-literal motion sentences on motor excitability as reflected by MEP changes during TMS stimulation. We compared in the same experiment four possible ways in which a motion verb can be used. We predicted to find activation of the motor system when the semantic motion component of the verb was preserved, as in literal, metaphorical and fictive motion sentences, but not in idiomatic motion sentences where the verb has no perceivable trace of abstract or concrete change of location. The MEPs response was largest with literal sentences, followed by fictive sentences and metaphorical motion sentences. The high motor excitability induced by metaphorical sentences confirmed our hypothesis based on the behavioral claim that the metaphorical use of a verb preserves the basic semantic component of the verb's meaning (Torreano et al., 2005). This finding is consistent with the results of Glenberg et al. (2008) who did not find any difference between abstract and concrete transfer sentences. The high motor excitability induced by fictive motion sentences observed in our study provides a direct test of motor system activation for this type of sentence. Indeed, previous studies (Saygin et al., 2010; Wallentin et al., 2005) claimed that fictive motion sentences activate cortical motion regions. However, in those studies the activated areas were motion-sensitive visual areas and not primary motor areas. In none of these studies were the MEPs measured, and none of them reported activation of the primary motor cortex.

We did not observe motor activation for idiomatic sentences. Even though many idioms originate from metaphors, this origin is often lost and remains unperceived by readers. As Aziz-Zadeh et al. (2006) noted, it is possible that once a metaphor is learned, it no longer activates the same network that it may have initially. That is, although a metaphor like 'grasping the situation' when first encountered may have utilized motor representations for its understanding, once it is overlearned it no longer relies on those representations.

Our lack of activation for idiomatic sentences disconfirms Boulenger et al.'s (2009) claim of activation of motor cortices for idiomatic sentences. However, in Boulenger et al.'s fMRI study motor activation occurred at a time window later than that of our TMS stimulation (see also Papeo, Vallesi, Isaja, \& Rumiati, 2009). This late activation could in part depend on individual comprehension strategies. Furthermore, Boulenger et al.'s results are critical to interpret because the activated areas include those active during idiom comprehension in general (Romero Lauro et al., 2008; Zempleni et al., 2007).

One might argue that idioms require a re-interpretation of the sentence that delays any MEP effect for idioms as compared to other types of sentence. Several considerations speak against this 
objection. First, after the end of the idiom string usually some words were inserted to conclude the sentence to also avoid wrap-up effects. The TMS was delivered at the end of the sentence, therefore there was plenty of time for re-interpretation, if any. Second, idioms were highly familiar, and a consistent body of evidence suggests that the figurative interpretation of familiar idioms is available at the end of the idiom string (Cacciari, Padovani, \& Corradini, 2007). Third, a re-interpretation might be expected even when participants read metaphorical motion sentences (only literal sentences do not require any re-interpretation), but in that case we found an increase of MEP amplitude. Indeed, we performed a previous experiment on eight healthy participants (six females, mean age $29 \pm 3$ years; mean education $17 \pm 1$ years; Handedness Inventory test mean score 97.4\%) using the same material and procedure, except that TMS was delivered immediately after the second segment, so that participants only read the noun phrase and the (motion or mental) verb before receiving TMS. This means that up to that point participants were unaware of the literal, metaphorical or idiomatic nature of the sentences (with the exception of sentences with an inanimate subject) that only emerged afterwards, when the final part of the sentence was presented. In this experiment the effect of the sentence type on motor cortical excitability was evaluated using the MEP changes expressed in terms of the ratio $(\Delta)$ between motion and mental (i.e., control) sentences. A repeated measure ANOVA with Sentence type (literal, fictive, idiomatic or metaphorical motion) as within-subject factor was used. The analysis did not show any significant effect either on the GCM muscle $[F(3,21)=.68$; $p=.57]$ or on the TA muscle $[F(3,21)=.14 ; p=.93]$. Finally, we did not want to interfere with the computation of the idiomatic (or metaphorical) meaning, but we aimed to assess whether this required the activation of the motor cortex. Indeed, a crucial point is that we did not use repetitive TMS to interfere with some stage of processing. We used single pulse TMS to evaluate whether changes in the MEPs amplitude were triggered and modulated by the different types of motion sentences used in the present study. TMS only had the function of assessing the involvement of the motor area in sentence interpretation. Crucially, we found that processing the sentence meaning involved the activation of the motor cortex for all types of sentences containing a motion verb, with the exception of idiomatic sentences. We cannot of course establish exactly when this activation took place, however it did occur only in cases in which the semantic motion component was preserved. Another important issue is that the location of the coil was based on maximal effect measured at the leg muscle; for that reason it might be that MEP measured at the hand showed no significant effects of stimulus type.

Idioms differ from metaphors (even though many idioms diachronically derive from metaphors) since metaphors do not have a unique standardized meaning and can convey more than one meaning (even a rather conventionalized metaphor as John is an elephant conveys different meanings, for instance that he is clumsy, extremely big, a gaffeur, etc.). Idioms do have a unique meaning that can be specialized but not changed by context. In contrast, we can create a metaphor on the fly, albeit not necessarily a good one. Metaphors require categorization processes (Cacciari \& Glucksberg, 1995), while idioms processing requires meaning retrieval from semantic memory. Therefore, metaphors maintain the original meaning of the constituent words, while this is generally lost in familiar idioms. The difference between these two types of figurative expressions is not only a matter of level of figuration, but also of the types of process involved.

Finally, the role of imagery remains a controversial issue. Many results, including ours, could reflect the contribution of motor imagery. This interpretation, as suggested by Willems and Hagoort (2007), cannot be easily discharged especially when considering the activation found in metaphorical sentences. Pulvermuller and collegues (Hauk \& Pulvermuller, 2004; Pulvermüller, Shtyrov, \& Ilmoniemi, 2005) have argued against this interpretation, since in a lexical decision task motor activation emerged early on, at around $200 \mathrm{~ms}$ (with differences between leg, arm and face words), a latency too early to reflect strategic effects such as imagery. In our experiment, the effect was found at a later interval, so possible imagery effects cannot be ruled out.

To sum up, we started by wondering whether the activation of the motor system was sensitive or not to the literal vs. figurative nature of the motion conveyed by a sentence. The answer emerging from this study is that the excitability of the motor system is modulated by how much the motor component of the verb is preserved. This is preserved in metaphorical motion sentences, regardless of the literal vs. figurative nature of the entities changing location, in line with Glenberg et al.'s results, and instead vanished in idiomatic sentences. Our results showed that this was indeed the case also for fictive motion sentences where presumably readers mentally scanned the space described by the sentence (Saygin et al., 2010; Talmy, 2000; Wallentin et al., 2005). While in previous studies motion sensitive visual areas were activated, we found that scanning the scenario induced motor activation.

In conclusion, our findings further corroborate the view that the semantic representation grounded in the sensory-motor system plays a role in processing sentential meaning. However, the activation of motor representations is strongly influenced by the linguistic context in which the motion verb occurs.

\section{Acknowledgments}

This study was supported by FAR grants to CC and CP. The authors are grateful to Arianna Fogliata for her help in the pilot experiments.

\section{References}

Aziz-Zadeh, L., Wilson, S. M., Rizzolatti, G., \& Iacoboni, M. (2006). Congruent embodied representations for visually presented actions and linguistic phrases describing actions. Current Biology, 16, 1818-1823.

Barsalou, L. W. (1999). Perceptual symbol systems. Behavioral and Brain Sciences, 22, 577-660.

Beilock, S. L., Lyons, I. M., Mattarella-Micke, A., Nusbaum, H. C., \& Small, S. L. (2008). Sports experience changes the neural processing of action language. Proceedings of the National Academy of Science, 105, 13269-13273.

Bertinetto, P. M., Burani, C., Laudanna, A., Marconi, L., Ratti, D., Rolando, C., \& Thornton, A.M. (2005). CoLFIS (Corpus e Lessico di Frequenza dell'Italiano Scritto) <http://www.istc.cnr.it/material/database/>.

Boulenger, V., Hauk, O., \& Pulvermüller, F. (2009). Grasping the ideas with the motor system: Semantic somatotopy in idiom comprehension. Cerebral Cortex, 19, 1905-1914.

Briggs, G. G., \& Nebes, R. D. (1975). Patterns of hand preference in a student population. Cortex, 11, 230-238.

Buccino, G., Riggio, L., Melli, G., Binkofski, F., Gallese, V., \& Rizzolatti, G. (2005). Listening to action-related sentences modulates the activity of the motor system: A combined TMS and behavioral study. Cognitive Brain Research, 24 355-363.

Cacciari, C., \& Papagno, C. (in press) Neuropsychological and neurophysiological correlates of idiom understanding: How many hemispheres are there involved? To appear. In Faust M. (Ed.), Handbook of the neuropsychology of language. Oxford: Oxford University Press.

Cacciari, C., \& Glucksberg, S. (1995). Understanding idioms: Do visual images reflect figurative meanings? European Journal of Cognitive Psychology, 7, 283-305.

Cacciari, C., Padovani, R., \& Corradini, P. (2007). Exploring the relationship between individuals' speed of processing and their comprehension of spoken idioms. European Journal of Cognitive Psychology, 19(3), 417-445.

Chen, E., Widick, P., \& Chatterjee, A. (2008). Functional-anatomical organization of predicate metaphor processing. Brain and Language, 107, 194-202.

Coren, S. (1993). The lateral preference inventory for measurement of handedness, footedness, eyedness, and earedness: Norms for young adults. Bulletin of the Psychonomic Society, 31, 1-3.

Devlin, J. C., \& Watkins, K. E. (2007). Stimulating language: Insights from TMS. Brain $130,610-622$

Fernandino, L., \& Iacoboni, M. (2010). Are cortical motor maps based on body parts or coordinated actions? Implications for embodied semantics. Brain and Language, 112, 44-53. 
Fischer, M. H., \& Zwaan, R. A. (2008). Embodied language: A review of the role of the motor system in language comprehension. Quarterly Journal of Experimental Psychology, 61, 825-850.

Galati, G., Committeri, G., Spitoni, G., Aprile, T., Di Russo, F., Pitzalis, S., et al. (2008) A selective representation of the meaning of actions in the auditory mirror system. Neuroimage, 40, 1274-1286.

Ghio, M., \& Tettamanti, M. (2010). Semantic-domain specific functional integration for action-related vs. abstract concepts. Brain and Language, 112, 223-232.

Glenberg, A. L., \& Robertson, D. A. (1999). Indexical understanding of instructions. Discourse Processes, 28, 1-26.

Glenberg, A. M., Sato, M., Cattaneo, L., Riggio, L., Palombo, D., \& Buccino, G. (2008). Processing abstract language modulates motor system activity. The Quarterly Journal of Experimental Psychology, 61, 905-919.

Hauk, O., \& Pulvermuller, F. (2004). Neurophysiological distinction of action words in the fronto-central cortex. Human Brain Mapping, 21, 191-201.

Martin, A. (2007). The representation of object concepts in the brain. Annual Reviews Psychology, 58, 25-45.

Matlock, T. (2004). Fictive motion as cognitive simulation. Memory $\mathcal{E}$ Cognition, 32, 1389-1400.

Papagno, C., \& Caporali, A. (2007). Testing idiom comprehension in aphasic patients: The modality and the type of idiom effects. Brain \& Language, 100, 208-220.

Papagno, C., Tabossi, P., Colombo, A., \& Zampetti, P. (2004). Idiom comprehension in aphasic patients. Brain and Language, 89, 226-234.

Papeo, L., Vallesi, A., Isaja, A., \& Rumiati, R. I. (2009). Effects of TMS on different stages of motor and non-motor verb processing in the primary motor cortex. PlosOne, 4, 2.

Patterson, K., Nestor, P. J., \& Rogers, T. T. (2007). Where do you know what you know? The representation of semantic knowledge in the human brain. Nature Reviews Neuroscience, 8, 976-987.

Postle, N., McMahon, K. L., Ashton, R., Meredith, M., \& de Zubicaray, G. I. (2008). Action word meaning representations in cytoarchitectonically defined primary and premotor cortices. Neuroimage, 43, 634-644.

Pulvermüller, F., \& Fadiga, L. (2010). Active perception: Sensorimotor circuits as cortical basis for language. Nature Reviews Neuroscience, 11, 351-360.

Pulvermüller, F., Shtyrov, Y., \& Ilmoniemi, R. (2005). Brain signatures of meaning access in action word recognition. Journal of Cognitive Neuroscience, 17, 884-892.

Raposo, A., Moss, H. E., Stamatakis, E. A., \& Tyler, L. K. (2009). Modulation of motor and premotor cortices by actionsm action words and action sentences. Neuropsychologia, 47, 388-396.
Richardson, D., \& Matlock, T. (2007). The integration of figurative language and static depictions: An eye movement study of fictive motion. Cognition, 102, 129-138.

Romero Lauro, L. J., Tettamanti, M., Cappa, S. F., \& Papagno, C. (2008). Idiom comprehension: A prefrontal task? Cerebral Cortex, 18, 162-170.

Rossi, S., Hallett, M., Rossini, P. M., Pascual-Leone, A., \& Safety of TMS Consensus Group (2009). Safety, ethical considerations, and application guidelines for the use of transcranial magnetic stimulation in clinical practice and research. Clinical Neurophysiology, 120, 2008-2039.

Rossini, P. M., Barker, A. T., Berardelli, A., Caramia, M. D., Caruso, G., Cracco, R. Q., et al. (1994). Non-invasive electrical and magnetic stimulation of the brain, spinal cord and roots: Basic principles and procedures for routine clinical application. Report of an IFCN committee. Electroencephalography Clinical Neurophysiology, 91, 79-92.

Rothwell, J. C., Day, B. L., Thompson, P. D., Dick, J. P., \& Marsden, C. D. (1987). Some experiences of techniques for stimulation of the human cerebral motor cortex through the scalp. Neurosurgery, 20, 156-163.

Sale, M. V., Ridding, M. C., \& Nordstrom, M. A. (2007). Factors influencing the magnitude and reproducibility of corticomotor excitability changes induced by paired associative stimulation. Experimental Brain Research, 181, 615-626.

Saygin, A. P., McCullough, S., Alac, M., \& Emmorey, K. (2010). Modulation of BOLD response in motion-sensitive lateral temporal cortex by real and fictive motion sentences. Journal of Cognitive Neuroscience, 22(11), 2480-2490.

Smith, M. J., Keel, J. C., Greenberg, B. D., Adams, L. F., Schmidt, P. J., Rubinow, D. A., et al. (1999). Menstrual cycle effects on cortical excitability. Neurology, 53, 2069-2072.

Talmy, L. (2000). Toward a cognitive semantics (vol. 2). Cambridge, MA: MIT Press.

Tettamanti, M., Buccino, G., Saccuman, M. C., Gallese, V., Danna, M., Scifo, P., et al. (2005). Listening to action-related sentences activates fronto-parietal motor circuits. Journal of Cognitive Neuroscience, 17, 273-281.

Torreano, L., Cacciari, C., \& Glucksberg, S. (2005). When dogs can fly: Level of abstraction as a cue to metaphorical use of verbs. Metaphor $\mathcal{E}$ Symbol, 20, 259-274.

Wallentin, M., Ostergaard, S., Lund, T. E., Østergaard, S., Østergaard, L., \& Roepstorff, A. (2005). Concrete spatial language: See what I mean? Brain and Language, 92, 221-233.

Willems, R. M., \& Hagoort, P. (2007). Neural evidence for the interplay between language, gesture, and action: A review. Brain and Language, 101, 278-289.

Zempleni, M. Z., Haverkort, M., Renken, R., \& Stowe, L. A. (2007). Evidence for bilateral involvement in idiom comprehension: An fMRI study. Neuroimage, 34 1280-1291. 